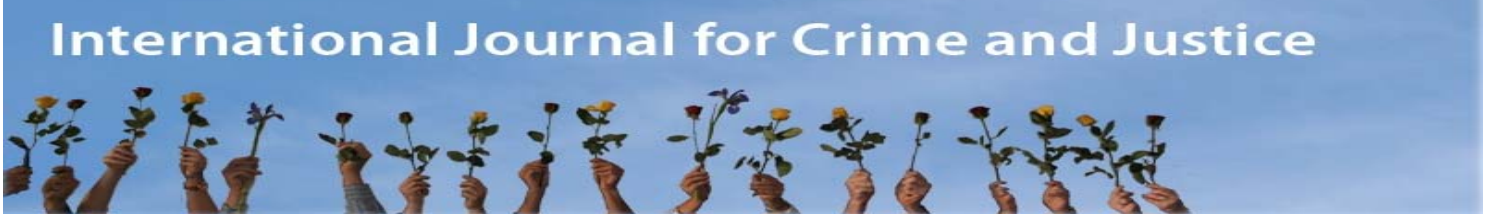

\title{
Prevention and Pre-emption in Australia's Domestic Anti-terrorism Legislation
}

\author{
Tamara Tulich 1 \\ University of New South Wales, Sydney
}

\begin{abstract}
The move towards prevention in domestic anti-terror law and policy was initially justified as an exceptional response to the exceptional threat of transnational terrorism following September 11, 2001. However, commonalities are discernable between prevention in antiterror law and prevention as employed in other areas of Australian law. To begin contextualising and analysing preventive practices in Australia, a framework is required. 'The preventive state' provides one way to view the collection of preventive measures employed in Australia. Engaging a governmentality perspective has the potential to make visible prevention and pre-emption in law and governance, and to inform critical treatment of the preventive state itself. Whether and how prevention and pre-emption in anti-terror law differ from and exhibit continuities with other preventive measures has the potential to expose issues of selectivity and proportionality between preventive measures and force consideration of the limits of state action to prevent or pre-empt harm.
\end{abstract}

\section{Keywords}

Anti-terrorism, Australia, legislation, pre-emption, prevention.

\section{Introduction}

In the wake of September 11,2001, the Australian government embraced a domestic anti-terror policy that prioritised the prevention of terrorism (Department of Prime Minister and Cabinet, 2006, 2010; Ruddock, 2007). Then Attorney General Phillip Ruddock championed prevention as a cornerstone of Australia's counter terrorism policy, by which the government sought to 'prevent rather than to react to terrorist offences' (Ruddock, 2007: 4). The policy objective of prevention permeates much of Australia's anti-terror legislation, with 54 anti-terror laws enacted by the Commonwealth Parliament in the decade following September 11 (Williams, 2011: 1144). Many of these laws are geared towards detection and early intervention to thwart a terrorist threat.

Prevention in Australia's domestic legal response to terror has ushered in a host of 'pre-crime' measures that permit the state to intervene and restrain an individual on the basis of an anticipated future harm, rather than past wrongdoing (Zedner, 2007a: 259). Prevention by liberty restraint is a feature of many anti-terror initiatives, most notably control orders and preparatory offences (Divs 101, 104, Criminal Code Act 1995 (Cth) 'Criminal Code). These measures deviate from the traditional retrospective and 'post-crime' orientation of the criminal justice system, where the state reacts and responds to harm by prosecuting and punishing criminal acts on the basis of evidence gathered about past events (Roach, 2010; Zedner, 2007a: 
259, 2009: 73). 'Pre-crime' measures are predictive and rely upon intelligence 'about future threats to security' gathered through surveillance practices and 'pre-crime' policing (Roach, 2010: 52; Walker, 2011: 56).

Australia's anti-terror laws were originally justified as exceptional measures in response to the exceptional threat of transnational terrorism following September 11 (McGarrity and Williams, 2010). Legislation aimed at preventing future harm by restricting an individual's liberty in the present is, however, neither new nor novel to the Australian legal system. Apprehended violence orders and binding over orders are examples of where parliaments have sanctioned restrictions upon an individual's liberty in order to avert harm. Prevention by liberty restriction is also a feature of post-sentence preventive detention and extended supervision orders in respect to serious sex offenders, such as are available in NSW pursuant to the Crimes (Serious Sex Offenders) Act 2006 (NSW).

This raises the question of whether prevention in anti-terror law is distinct from prevention in other areas of Australian law, and what we might learn from examining continuities and discontinuities between preventive measures. In order to answer this question a framework is required to begin contextualising and analysing preventive practices in Australia. This paper argues that 'the preventive state' provides a useful conceptual framework through which to view the collection of preventive measures in Australian law. In order to subject preventive law and governance as well as the preventive state itself to critical analysis, further tools are needed. It is here that a governmentality perspective has much to offer scholarship on the preventive state, providing a textured account of preventive governance and informing critique of the preventive state concept. Whether and how preventive measures are new or different in form or operation raises important questions about how we govern and are governed, about selectivity in prevention by liberty restraint, and where the limits lie of state action to prevent harm.

\section{The preventive state}

While originally justified as exceptional and temporary measures to meet an exceptional threat, the commonalities between prevention in anti-terror law and preventive measures employed in other areas of Australian law warrant further consideration. Dershowtiz, for example, traces the use prevention by liberty restraint of persons deemed dangerous 'to illustrate a more general phenomenon, namely, that preemptive actions of many kinds have been far more common in practice than they appear in theory' (Dershowitz, 2006: 58). An investigation of preventive measures in Australia may reveal that prevention and pre-emption in anti-terror law form part of a broader pattern of preventive governance (Tulich, 2012).

The rise of prevention (loosely defined as state interventions that target an identified threat before it eventuates) and pre-emption (broadly describing state interventions to 'target threats before they emerge' (McCulloch and Pickering, 2010: 15-17)) in anti-terror law may be examined in the context of a broader transformation of governance and society, influenced by an increasing preoccupation with risk, uncertainty and (in)security (Beck, 1992; Ericson, 2007; Zedner 2009). One way in which the fixation on risk, uncertainty and insecurity has wrought change is in a shift in emphasis in governance from a 'reactive' or 'punitive' state, where the state intervenes after harm occurs, to 'the preventive state' in which the state seeks to intervene before harm occurs (Dershowitz, 2009; Steiker, 1998).

The preventive state is a useful way to conceptualise the impetus for prevention in domestic anti-terror law. Steiker first coined the preventive state in 1998, prior to the so called 'war on terror', to describe the disparate collection of measures employed in the United States to 'prevent or prophylactically deter (as opposed to investigate) crime and to incapacitate or treat (as opposed to punish) wrongdoers' (Steiker, 1998: 806). Following September 11, 
commentators have identified prevention in anti-terror law as a manifestation of the preventive state, where the state seeks to prevent or pre-empt harm by targeting those deemed 'dangerous' and restricting their liberty before they cause harm, such as by preventatively detaining an individual to forestall a terrorist attack (Ashworth 2009; Ashworth and Zedner, 2008; Janus 2004, 2006; Steiker 1998).

In invoking the preventive state, Steiker identified two issues that are of continued relevance to Australia. First, any attention that was given to preventive measures was limited to the question of whether a measure amounted to prevention or punishment (Steiker, 1998: 776-7). In Australia, the question of whether a measure is punitive or not has, for good reason, garnered a great deal of commentary and analysis by the courts, as this distinction has implications for the constitutional validity of detention (Gordon, 2012; McDonald, 2007). Punitive detention, for example, may only be ordered by a court, subsequent to the adjudication of criminal guilt, by virtue of the strict separation of judicial power (Chu Kheng Lim v Minister for Immigration, Local Government and Ethnic Affairs (1992) 176 CLR 1, per Brennan, Deane and Dawson JJ at 27). However, Steiker's concern was that preoccupation with the preventive/punitive distinction obscured broader inquiry into the scope and limits of the preventive state. It also led, she argued, to the 'mistaken impression' that if the state was not punishing but preventing crime and disorder, its actions were unobjectionable (Steiker, 1998: 784).

The second issue Steiker identified was that the limits of state action to prevent harm ought to be articulated and enforced, as are those of the punitive state. The scope and limits of the state as punisher are well established and policed, yet the limits of the preventive state remain largely neglected (Steiker, 1998: 773-4). Preventive measures were not being investigated cohesively but 'treated as sui generic', with 'few connections ... made between the main categories of preventive restraints, such as pre-trial detention, civil commitment of the dangerous mentally ill' (Steiker, 1998: 778). In Australia, scant regard has been paid to the collection of preventive laws employed by governments, the connections and disconnections between them and the challenges to which they give rise. ${ }^{2}$ Appreciating how preventive measures are distinct and similar has the potential to inform and enhance 'discussion about the appropriate limits to be placed upon the preventive state' (Zedner, 2007b: 190). The preventive state affords one way in which attention may be given to developing a more cohesive preventive jurisprudence in Australia and to articulating what principles, values and limits attach to state action that seeks to prevent future harm by restricting liberty in the present (Zedner, 2007b).

The preventive state serves as an umbrella concept to describe and encompass state action which seeks to anticipate and avert or minimise harm; that is, state action in furtherance of a particular objective - the prevention of harm. This is not to suggest that the preventive state is displacing the punitive state where the state acts in furtherance of the objective of punishment. Rather, preventive measures are increasingly employed by governments and serve to broaden the boundaries of the criminal justice system (Ashworth, 2009: 87-8). The preventive state is deliberately pitched at a high 'level of conceptual generalization' to facilitate the collation and investigation of the array of preventive measures employed by governments (Steiker, 1998: 779-80). Nonetheless, laws that fall within the ambit of the preventive state may be said to share two features: a preventive nature; and a future orientation (Ashworth and Zedner, 2008). The first draws attention to the purpose and effect of the law; the second to its predictive component.

Characterising a law as preventive is a difficult task that goes beyond legislative designation. A legislative label of prevention does not, for example, automatically shield a law from being punitive in substance or effect, or from attracting a punitive sanction (Tulich, 2012). Prevention and punishment are neither easily distinguishable nor mutually exclusive. The task of sentencing usefully illustrates this, combining as it does preventive and punitive purposes. As 
members of the High Court stated in Veen v The Queen (No 2) (1988) 164 CLR 465 at 476 (per Mason CJ, Brennan, Dawson and Toohey JJ):

The purposes of criminal punishment are various: protection of society, deterrence of the offender and of others who might be tempted to offend, retribution and reform. The purposes overlap and none of them can be considered in isolation from the others when determining what is an appropriate sentence in a particular case.

Preparatory offences may be said to be preventive in nature: their aim is to prevent a terrorist act by interrupting it, even though they also constitute substantive offences for acts taken that are preparatory to a terrorist act and attract custodial sentences. Whealy J in his remarks on sentence in $R v$ Lodhi [2006] NSWSC 691, which related to three preparatory offences, stated at [51]:

the legislation under which these offences has been created was specifically set up to intercept and prevent a terrorist act at a very early or preparatory stage, long before it would be likely to culminate in the destruction of property and the death of innocent people. The very purpose of the legislation is to interrupt the preparatory stages leading to the engagement in a terrorist act so as to frustrate its ultimate commission.

Control orders under Division 104 of the Criminal Code are similarly preventive. They enable restrictions, prohibitions and obligations to be placed on a person 'for the purpose of protecting the public from a terrorist act' (s 104.1, Criminal Code). Control orders are predictive and are imposed to prevent future harm from occurring, albeit attracting a punitive sanction of a maximum of 5 years imprisonment on breach.

A future orientation captures legislative attempts to govern the future by sanctioning intervention that preventively restrains an individual's liberty in the present (Ashworth and Zedner, 2008: 21). 'Future law,' (Ashworth and Zedner, 2008: 42) and 'Future Governance' (Crawford, 2009: 819) have been coined to describe these efforts. Future governance permits the state to intervene and restrict a person's liberty to avert an anticipated future harm, enabling intervention at points in time well before, and well after, that which is traditionally accepted in the criminal justice system. Such intervention occurs on the basis of a lower threshold of knowledge: the further removed intervention is from the harm to be prevented, the lower the threshold of knowledge to found intervention.

A future orientation also gives rise to new modes of governance, such as 'the bid to control future behaviour through strategies of self-governance' (Ashworth and Zedner, 2008: 41). This is what Crawford terms 'contractual governance' or 'regulated self-regulation', which he argues represents 'a shift in regulatory style' and the mode by which individuals are increasingly governed (Crawford, 2003: 487). By contractual governance, the state seeks to control the future behaviour of an individual through a 'contractual arrangement'. Many Australian examples of contractual governance are also civil/criminal hybrid orders; that is, orders that are civil in nature, yet attract criminal penalty on breach. This is true of anti-terror and serious organised crime control orders, and extended supervision orders in respect of serious sex offenders. These orders are said to be self-regulating and induce self-policing: they work on the assumption that an individual subject to an order will, acting in rational self interest, voluntarily comply with the order so as avoid the consequences of breach (Ashworth and Zedner, 2008).

The introduction of preparatory offences in Division 101 of the Criminal Code provides a good example of the future orientation and preventive push in domestic anti-terror law. The preparatory offences establish criminal responsibility 'at an earlier stage than is usually the case 
for other kinds of criminal conduct;, for example, well before an agreement has been reached for a conspiracy charge' and well before the person has 'decided precisely what he or she intends to do' (Lodhi $v R$ [2006] NSWCCA 121 at [66] per Spigelman CJ). The introduction of preparatory offences has enabled criminal liability to arise at points in time prior to inchoate liability, extending the reach of the criminal law.

In March 2002, the Howard government introduced the Security Legislation Amendment (Terrorism) Bill 2002 [No. 2] (Cth) into parliament to create the offence of engaging in an act of terrorism as well as four preparatory offences. This Bill received Royal Assent in July of that year. The substantive offence of engaging in an act of terrorism attracts a maximum penalty of life imprisonment (Criminal Code, s101.1). To this offence attaches inchoate liability, notably attempt and conspiracy contained in ss 11.1 and 11.5 of the Criminal Code. While inchoate liability is not uncontroversial, in that it enables the state to intervene to prosecute and punish a person who intends to cause harm but who has not yet done so (MacDonald and Williams, 2007: 33-35; McSherry, 2009), it is at this point that the criminal law traditionally marks criminal liability.

Preparatory offences criminalise acts and associations that are further removed from the commission of a terrorist act, and in doing so create pre-inchoate liability (see Ashworth and Zedner 2011: 285-6; Tulich, 2012). The first three species of preparatory offence are similarly constructed. A person commits an offence if he or she 'provides or receives training', 'posses a thing' or 'collects or makes a document' that is 'connected with the preparation for, the engagement of a person in, assistance in a terrorist act' and the person knows of, or 'is reckless as to the existence of', the connection (ss101.2, 101.4-5, Criminal Code). Where knowledge of the connection is established, the maximum penalty for involvement in training is 25 years imprisonment, with the other two offences attracting a maximum of 15 years imprisonment. If recklessness as to the existence of the connection is established, the maximum penalty for involvement in training is 15 years imprisonment, with 10 years attaching to the offences of possessing a thing and collecting or making a document.

The forth preparatory offence, which captures the widest conduct, attracts a maximum penalty of life imprisonment. A person commits an offence if the he or she 'does any act in preparation for, or planning, a terrorist act' (s101.6, Criminal Code). In respect to all of the preparatory offences, an offence is committed even if a 'terrorist act does not occur'; if the training/thing/document is not connected with, or the person's act is not done, 'in preparation for, the engagement of a person in, or assistance in a specific terrorist act'; or the training/thing/document/the person's act 'is connected with preparation for, the engagement of a person in, or assistance in a more than one terrorist act' (ss101.2(3), 101.4 (3), 101.5(3), 101.6(2), Criminal Code).

The breadth of the preparatory offences is compounded by the fact that to each of the four offences attaches inchoate liability. For example, it is an offence to attempt to do an act in preparation for a terrorist act pursuant to ss11.1 and 101.6 of the Criminal Code. This creates something in the order of pre-pre-inchoate liability, further elongating the boundaries of the criminal law (Tulich, 2012). The inchoate offence of attempt, as noted, is 'punishable as if the offence attempted had been committed' (s11.1, Criminal Code). The maximum penalty for the offence of attempting to do an act in preparation for a terrorist act is, therefore, life imprisonment (101.6, Criminal Code.).

The extension of criminal liability to preparatory offences and pre-pre-inchoate liability involves the criminalisation of acts taken well before, and further removed from harm, than that which is traditionally accepted in Australian criminal law while subjecting an individual to the severest range of penalties available under the Criminal Code. MacDonald and Williams point out that these offences thereby 'render individuals liable to very serious penalties even before 
there is clear criminal intent' (MacDonald and Williams, 2007: 34). The creation of preparatory offences is not a common occurrence; as Spigelman CJ noted in Lodhi $v$ at [66]:

Preparatory acts are not often made into criminal offences. The particular nature of terrorism has resulted in a special, and in many ways unique, legislative regime.

Just how unique or different prevention in anti-terror law is to that employed in other areas of Australian law, and whether relevant similarities exist, warrants further consideration. Such an inquiry has the potential to critically assess whether prevention in anti-terror law is exceptional, or as exceptional as claimed. However, there is only so much work the preventive state, as a general conceptual framework, can do. It does not, for example, provide the analytical tools to investigate and critique action taken within it, or the effects produced (Tulich, 2012). The governmentality perspective has much to offer scholarship of the preventive state; it provides tools to analyse law and governance of the preventive state in a textured and reflective manner, exposing the preventive state itself to critical treatment.

\section{An analytical perspective: Governmentality}

The governmentality perspective derives from Foucault's lectures at the Collège de France in 1978 (Foucault, 2007). For the purpose of this paper, the relevant meaning of 'governmentality' is an inquiry into the art of government, into the craft of governing: the practices, institutions, procedures and programmes through which we govern and are governed (Dean, 2010: 27-28; Foucault, 2007: 108)). This form of analysis, then, entails identifying (Rose et al., 2006: 83):

these different styles of thought, their conditions of formation, the principles and knowledges that they borrow from and generate, the practices they consist of, how they are carried out, their contestations and alliances with other arts of governing.

This governmentality approach stems from Anglophonic governmentality scholarship. This scholarship is diverse and varied, yet shares an analytical perspective. Bröckling, Krasmann and Lemke describe this as a 'research perspective in the literal sense: an angle of view, a manner of looking, a specific orientation' into the art of government, rather than a prescribed and distinct methodological 'inventory' (Bröckling et al., 2011: 11).

It is this analytical perspective that a governmentality lens can contribute to scholarship on the preventive state: it provides a way of viewing the practices and institutions of government orientated to the specific ideal of harm prevention. A more textured account may be had by scrutiny of mechanisms of power - law being one way in which power is exercised - and giving attention to how we are governed; by unpacking the rationality or logic influencing future governance in different settings; and by examining the practices that direct conduct as part of this rationality.

Many commentators have observed a new precautionary logic influencing thought and action of individuals and governments in the $21^{\text {st }}$ century (see, for instance, Ericson, 2007; Zedner, 2009). Precaution is a product of the increasing preoccupation with uncertainty and aversion of risk. Aradau and van Munster (2007: 91) argue that:

What is new is not so much the advent of a risk society as the emergence of a 'precautionary' element that has given birth to new configurations of risk that require that the catastrophic prospects of the future be avoided at all costs. 
The precautionary principle, originally arising in environmental regulation in respect to harms of potentially catastrophic and irreversible impact, is increasingly discussed as a regulatory tool in international law, risk regulation and security studies (Fisher, 2001: 315; McSherry and Keyzer, 2009; Stern and Wiener, 2006; Sunstein, 2005: 16). The precautionary principle has been the subject of much commentary, yet its precise content is not settled (Ewald, 1999; Sunstein, 2005). A precautionary approach promotes action by regulators 'to protect against potential harms, even if the causal chains are unclear' and uncertainty exists as to whether the harms will 'come to fruition' (Sunstein, 2005: 4). In the anti-terror context the harm requirement has been lowered: state intervention now occurs where harms are of lesser severity than catastrophic and irreversible (Zedner, 2009: 84).

A precautionary element is evident in law and policy of the Australian government, albeit without the government directly advocating the precautionary principle against terrorism (Bronitt, 2008: 79). For example, Senator Chris Ellison, then Minister for Justice and Customs, justified preparatory offences to the Senate as follows:

In the security environment that we are dealing with, you may well have a situation where a number of people are doing things but you do not yet have the information which would lead you to identify a particular act ... When you are dealing with security, you have to keep an eye on prevention of the act itself as well as bringing those who are guilty of the act to justice (Australia, Senate 2005: 43 cited in MacDonald and Williams, 2007: 34).

Precaution may be understood as the rationale that drives law and policy of the preventive state. The practices that direct conduct in furtherance of this precautionary logic are seen through the techniques of prevention and pre-emption. While sharing a precautionary logic, prevention and pre-emption are conceptually distinct and may be distinguished according to the point at which they permit intervention by the state, and the requisite knowledge threshold to found intervention. By investigating these two techniques we can start viewing, and importantly comparing, how law operates inside the preventive state.

Massumi's analysis of prevention and pre-emption furnishes key insights for distinguishing between these concepts in domestic legislation (Massumi, 2007; Tulich, 2012). Following September 11, the terms employed to describe anticipatory action taken by governments prevention, pre-emption and precaution - have been extensively and inconsistently employed (Tulich, 2012). Valverde expressed it well when she reported that '[t]he term 'security' is now doing a great deal of work in a wide variety of fields' (Valverde, 2011: 4). Similarly, prevention, pre-emption and precaution are doing a great deal of work in a great many disciplines. Their inconsistent usage reflects the different perspectives of those in government and academia, and the difficulties associated with migrating terminology between disciplines and jurisdictions. This has hindered meaningful analysis of domestic legal responses to terror (Tulich, 2012).

Massumi's account provides a comprehensive examination of prevention and pre-emption. For Massumi, prevention and pre-emption both operate 'in the present on a future threat' and are orientated towards neutralising that threat (Massumi, 2007: para. 13). However, in order to do so they rely upon distinct knowledge premises. Prevention achieves neutralisation of threat by acquiring the capability to prevent a threat. As such, underlying prevention is the assumption that it is possible to empirically assess a threat, identify its causes and adopt a method to neutralise it (para. 5). The epistemological premise of prevention is that the world is objectively knowable; uncertainty arises from a 'lack of information' and the trajectory of an event is predictable and linear (para. 5). Pre-emption, by contrast, operates in conditions of uncertainty. Unlike prevention where uncertainty results from a deficiency of information, for pre-emption, uncertainty arises because the threat has not emerged. As the risk of harm has not arisen, the threat is indeterminate; neither the threat nor the enemy can be specified (para. 13). 
Uncertainty about the nature of the threat is insurmountable; it cannot be overcome by the provision of information, and gives rise to potential politics and reliance upon the subjunctive: 'could have', 'if', 'would have' (para. 17).

Massumi's distinction between prevention and pre-emption in terms of the timing of intervention and the knowledge threshold provides a basis upon which to distinguish between preventive measures in domestic law (Tulich, 2012). Pre-emption and prevention are comprised of prediction and intervention. Prediction draws attention to the status of knowledge, and intervention to how strategies of prevention and pre-emption are conceived (Freeman, 1992). Pre-emption rests on the knowledge premise that the future is incalculable and is organised around uncertainty. Intervention occurs when a threat of harm is emergent but not determinate. This translates, for example, into intervention not only prior to harm occurring, or the commission of a criminal act, but also prior to the formation of clear criminal intent to commit the harm sought to be avoided (Ericson, 2007; MacDonald and Williams, 2007). Intervention occurs ahead of the risk of harm developing.

Because pre-emption permits interventions that are so far removed from the anticipated harm, the knowledge upon which intervention is based is lower. Pursuant to Australia's anti-terror control order regime, for example, a senior AFP officer, in obtaining consent of the Attorney General to request an interim control order, must either consider on reasonable grounds that the order would substantially assist in preventing a terrorist act or suspect on reasonable ground that the person has provided or received training from a listed terrorist organisation (s 104.2, Criminal Code). The first criterion enables pre-emption, facilitating intervention on the basis of 'an estimate of some future act, not necessary one to be committed by the person subject to the proposed order' (Thomas v Mowbray [2007] 233 CLR 307 per Kirby J at [357]). In order that an interim control order be issued on the basis of this predictive criterion, a court must be satisfied to the civil standard of the balance of probabilities that a control order would 'substantially assist in preventing a terrorist act' and the terms of the order are 'reasonably necessary, and reasonably appropriate and adapted' to 'protecting the public from a terrorist act' (s104.4, Criminal Code). Being so removed from the harm to be averted, pre-emption licenses action on the basis of intelligence and threat assessments.

Prevention provides a framework for a decision maker to assess the likelihood and degree of a threat prior to acting (Zedner, 2008: 46). Action is taken on the basis of a risk prediction; risk provides the logic or justification for intervention (Zedner, 2008). Prevention, as noted, assumes it is possible to assess with accuracy and objectivity the risk an individual poses. In this way, it presumes that the future is calculable, a premise underlying risk assessments (Zedner, 2008). Being temporally closer to the risk of harm sought to be averted, intervention occurs upon a higher threshold of knowledge.

Applying this framework to the example of the preparatory terrorism offences reveals an appreciable emphasis on pre-emption in domestic anti-terror law (Tulich, 2012). The substantive offence of engaging in a terrorist act, under s101.1 of the Criminal Code, is an example of the 'punitive state' and a 'post-crime' intervention. Here state intervention occurs after the commission of a terrorist act, after criminal intention is formed to commit the substantive offence. The inchoate offence of attempting to engage in a terrorist attack is an example of prevention. The state intervenes prior to the commission of the substantive offence, but after there have been 'acts more than merely preparatory' to the offence and the formation of the requisite intention to commit the substantive offence (s11, Criminal Code). This is the threshold at which the risk or likelihood of the offence justifies intervention.

The preparatory offence of doing an act in preparation for a terrorist attack, pursuant to s106.1 of the Criminal Code, is an example of pre-emption. The state intervenes before the crime occurs and prior to the commission of 'acts more than merely preparatory' to the offence. This risk of 
harm - the terrorist act - has not yet arisen; the threat of harm is emergent but not determinate. As Whealy J stated $R v$ Lodhi (2005) 199 FLR 236, at 246:

an offence will have been committed by a person acting in a preliminary way in preparation for a terrorist act even where no decision has been made finally as to the ultimate target.

Inchoate liability attached to the preparatory offences provides further examples of preemption, enabling intervention to occur prior to the commission of a preparatory offence.

From this starting point, analysis may be had of the various forms of knowledge relied upon and the effects produced by pre-emption and prevention in different settings. How, for example, does the increasing reliance upon national security intelligence as secret evidence in court proceedings - disclosure of which is not made to the individual subject to the proceedings impact upon the relationship between the individual and the executive? It may also generate inquiry into identity and how different forms of knowledge define those subject to preventive or pre-emptive practices (Dean, 2010: 32). These inquiries may inform articulation of the limits of preventive action by making visible the operation of preventive laws and exposing dissonance between how preventive laws are conceived and operate.

Governmentality scholarship may also inform fruitful critique of the preventive state itself and the scale of analysis it employs. Whilst Steiker adopted the term 'state' in conjunction with 'preventive' to describe 'any sovereign governmental power', as opposed to state governments in a federal system (Steiker, 1998: 773, n. 19), critical attention has not focused on the role of the state in this analysis or the broader utility of the scale of analysis adopted. A governmentality lens, for example, may inform critique of the state as a useful category of analysis (Dean, 2010: 33-37). Scaling down the analysis to a micro-analytical approach may better serve to expose the reality and operation of preventive governance. It may draw attention to the fact that what is being described signifies a mode of governance, 'future governance' (Crawford, 2009: 819) or 'preventive governance', elements of which may be present in a range of governmental practices.

\section{Implications and conclusion}

This paper has sought to briefly explore implications of the rise of prevention and pre-emption as part of Australia's anti-terrorism framework. The conceptual model of the preventive state provides one mechanism through which to begin to appreciate these broader implications, focusing as it does attention on the diverse collection of preventive measures employed by governments. However, the preventive state has limitations: engaging a governmentality perspective has the potential to make visible prevention and pre-emption in law and governance, and inform critique of the preventive state itself. Drawing connections and discontinuities between preventive measures is a critical step in engendering a broader preventive jurisprudence, through which the scope and limits of the preventive state may be considered and articulated.

This paper provides but a brief overview of one way to begin to conceptualise the preventive push in anti-terror law and draw connections between the diverse set of preventive measures that exist in Australia. The scale and pace of the enactment of anti-terror laws and the impact of these measures on our legal system has to date garnered much attention, illustrating how antiterror laws have realigned our legal system 'through the extensive powers they grant to government and their impact on basic freedoms' (Lynch and Williams, 2006: 85-6). Yet these measures may not be as unique, exceptional or isolated as heralded on enactment. Examples of future governance and prevention by liberty restraint abound for post-sentence interventions in relation to serious sex offenders, and involuntary detention of persons with mental illness. 
The modelling of anti-terror laws in state governmental responses to organised crime further suggests the exceptionality of anti-terror laws warrants enhanced scrutiny (Appleby and Williams, 2010; Lynch, 2009; McGarrity and Williams, 2010).

An additional justification for adopting and pursuing the preventive state model is that drawing connections between the diverse set of preventive measures may avoid dangers discovered in one measure being blindly reproduced in another (Zedner, 2007b: 189). It may also uncover where anti-terror laws differ from other preventive practices, giving rise to broader questions as to proportionality between preventive measures and selectivity in who is the subject of preventive interventions. For example, in contrast to serious sex offender orders which are imposed post sentence, anti-terror control orders may be imposed in the absence of criminal charge or adjudication of guilt (Lynch, 2009). Questions may properly be raised about why this is so, and where acceptable limits of state action to prevent harm lie.

Similarly, the extension of criminal liability to preparatory offences and by hybrid civil/criminal orders highlights the need to scrutinise the ambit of preventive practices. Preparatory offences, as noted, enable an individual to be subjected to the severest penalties available under the Criminal Code for acts taken at points in time prior to the enlivening of inchoate liability. This liability thus arises prior to the formation of intent to commit the substantive offence, and prior to the risk of harm. Control orders, by their hybrid civil/criminal design, enable restrictions to be imposed upon an individual's liberty, such as electronic tagging, whilst 'side-stepping' the enhanced procedural protections that attach to the criminal justice system (Zedner, 2007c). Ericson put it well when he wrote:

Precautionary logic leads to criminalization through counter-law ... New laws are enacted and new uses of existing law are invented to erode or eliminate traditional principles, standards, and procedures of criminal law that get in the way of pre-empting imagined sources of harm. (Ericson, 2009: 24)

Whether prevention and pre-emption are possible without corroding the integrity of the criminal justice system remains a pertinent issue.

Of further concern is how prevention and pre-emption may compound exclusion through the criminal justice system, as these measures predominantly affect marginalised and excluded members of society, such as the mentally ill, serious sex offenders, and terrorist suspects. In Australia, 37 persons have been charged with terrorism related offences, of which the overwhelming majority have been Muslim men, and all but one of the 'proscribed' terrorist organisations under Division 104 of the Criminal Code have been Muslim groups (McGarrity, 2010: 117; Attorney-General Hon. Robert McClelland MP, 2011). Moreover, the civil liberties concerns raised by commentators as to the dangers of blindness to the limits of the preventive state (Ashworth and Zedner, 2008; Dershowitz, 2009; Zedner, 2007a, 2007b, 2007c, 2008) are amplified in the Australian context, where reliance cannot be placed on a federal bill of rights (Lynch and Williams, 2006; Williams, 2011).

The rapid development of Australia's preventive anti-terror regime raises important questions about how we govern and are governed, and how prevention in anti-terror law should be understood within the Australian legal system (Tulich, 2012). It forces consideration of the acceptable limits of state action to prevent harm and how unprecedented and exceptional preventive anti-terror laws in fact are. Exploring continuities and distinctions between prevention and pre-emption in anti-terror law and that employed in other areas of Australian law as part of a broader shift in emphasis in governance has the potential to raise new questions about proportionality and selectivity in preventive practices, as well as the rapid development of Australia's preventive anti-terror regime and the modelling of its innovations in other areas of law. 
Correspondence: Tamara Tulich, PhD Candidate, Nettheim Doctoral Teaching Fellow, Faculty of Law, University of New South Wales, Sydney NSW 2052, Australia.Email: t.tulich@unsw.edu.au

1 Supported by the Australian Research Council Laureate Fellowship Project 'Anti-Terror Laws and the Democractic Challenge'. A version of this paper was presented at the Crime, Justice and Social Democracy conference at Queensland University of Technology, 28 September 2011. I thank the conference organisers, Kerry Carrington and Juan Tauri, and participants. I am grateful to Fergal Davis and George Williams for their comments on an earlier draft of the presentation. All errors of course remain my own.

2 Although notable efforts have been made: see Meyerson D (2009) Risks, rights, statistics and compulsory measures. Sydney Law Review 31: 507-535.

\section{References}

Appleby G and Williams J (2010) The anti-terror creep: Law and order, the States and the High Court of Australia. In McGarrity N, Lynch A and Williams G (eds) Counter-Terrorism and Beyond: The Culture of Law and Justice After 9/11. Abingdon: Routledge: 150-169.

Aradau C and van Munster R (2007) Governing terrorism through risk: Taking precautions, (un)knowing the future. European Journal of International Relations 13: 89-115.

Ashworth A (2009) Criminal law, human rights and preventative justice. In McSherry B, Norrie A and Bronitt S (eds) Regulating Deviance: The Redirection of Criminalisation and the Futures of Criminal Law. Oxford: Hart Publishing: 88-108.

Ashworth A and Zedner L (2008) Defending the criminal law: Reflections on the changing character of crime, procedure, and sanctions. Criminal Law and Philosophy 2: 21-51.

Ashworth A and Zedner L (2011) Just prevention: Preventive rationales and the limits of the criminal law. In Duff R and Green S (eds) Philosophical Foundations of Criminal Law. Oxford: Oxford University Press: 279-303.

Attorney-General Hon. Robert McClelland MP (2011) Address to the United States Studies Centre: The 9/11 decade. United States Studies Centre 2011 National Summit The 9/11 Decade: How Everything Shanged, 6-7 June, Sydney.

Beck U (1992) Risk Society. London: Sage.

Bröckling U, Krasmann S and Lemke T (2011) From Foucault's lectures at the Collège de France to studies in governmentality: An introduction. In Bröckling U, Krasmann S and Lemke T (eds) Governmentality: Current Issues and Future Challenges. New York: Routledge: 1-33.

Bronitt S (2008) Balancing security and liberty: Critical Perspectives on terrorism law reform. In Gani M and Mathew P (eds) Fresh Perspectives on the 'War on Terror'. Canberra: ANU E Press: 65-83.

Crawford A (2003) Contractual Governance of Deviant Behaviour. Journal of Law and Society 30: 479-505.

Crawford A (2009) Governing through anti-social behaviour. British Journal of Criminology 49: 810-831.

Dean M (2010) Governmentality: Power and Rule in Modern Society. London: Sage.

Department of Prime Minister and Cabinet (2010) Counter-terrorism White Paper-Securing Australia, Protecting Our Community. Canberra: Commonwealth of Australia.

Dershowitz AM (2006) Pre-emption: A Knife that Cuts both Ways. New York: WW Norton and Company.

Dershowitz AM (2009) The preventive state: Uncharted waters after 9/11. In Morgan M J (ed) The Impact of $9 / 11$ and the New Legal Landscape: The Day that Changed Everything? New York: Macmillan: 7-24.

Ericson RV (2007) Crime in an Insecure World. Cambridge: Polity.

Ewald F (1999) The return of the crafty genius: An outline of a philosophy of precaution. Connecticut Insurance Law Journal 6: 47-79.

Fisher E (2001) Is the precautionary principle justiciable? Journal of Environmental Law: 13: 315-334. 
Foucault M (2007) Security, Territory, Population: Lectures at the Collège de France, 1977-1978. Hampshire: Palgrave Macmillan.

Freeman R (1992) The idea of prevention: a critical overview. In Scott S, Williams G, Platt S and Thomas H (eds) Private Risks and Public Dangers. Aldershot: Avebury: 34-56.

Gordon JS (2012) Imprisonment and the separation of judicial power: a defence of a categorical immunity from non-criminal detention'. Melbourne University Law Review 36: 41-103.

Janus ES (2004) The preventive state, terrorists and sexual predators: Countering the threat of a new outsider jurisprudence. Criminal Law Bulletin 40(6): 596-598.

Janus ES (2006) Failure to Protect. Ithaca: Cornell University Press.

Lynch A (2009) Terrorists and bikies: The constitutional licence for laws of control. Alternative Law Journal 34(4): 237-242.

Lynch A and Williams G (2006) What Price Security? Taking Stock of Australia's Anti-Terror Laws. Sydney: University of New South Wales Press Ltd.

McCulloch J and Pickering S (2010) Counter-terrorism: the law and policing of pre-emption. In McGarrity N, Lynch A and Williams G (eds) Counter-Terrorism and Beyond: The Culture of Law and Justice after 9/11. Abingdon: Routledge: 13-29.

McDonald S (2007) Involuntary detention and the separation of judicial power. Federal Law Review 35(1): 25-79.

MacDonald E and Williams G (2007) Combating terrorism: Australia's Criminal Code since September 11, 2001. Griffith Law Review 16(1): 27-54.

McGarrity N (2010) 'Testing' our counter-terrorism laws: The prosectuion of individuals for terrorism offences in Australia. Criminal Law Journal 34: 92-127.

McGarrity N and Williams G (2010) When extraordinary measures become normal: pre-emption in counter- terrorism and other laws. In McGarrity N, Lynch A and Williams G (eds) CounterTerrorism and Beyond: The Culture of Law and Justice After 9/11. Abingdon: Routledge: 131149.

McSherry B (2009) Expanding the boundaries of inchoate crimes: The growing reliance on preparatory offences. In McSherry B, Norrie A and Bronitt S (eds) Regulating Deviance: The Redirection of Criminalisation and the Futures of Criminal Law. Oxford: Hart Publishing: 143164.

McSherry B and Keyzer P (2009) Sex Offenders and Preventive Detention: Politics, Policy and Practice. Sydney: Federation Press.

Massumi B (2007) Potential politics and the primacy of preemption. Theory and Event 10(2). Available at http://muse.jhu.edu/journals/theory_and_event/toc/tae10.2.html (accessed 19 October 2012).

Roach K (2010) The eroding distinction between intelligence and evidence in terrorism investigations. In McGarrity N, Lynch A and Williams, G (eds) Counter-Terrorism and Beyond: The Culture of Law and Justice After 9/11. Abingdon: Routledge: 48-68.

Rose N, O'Malley P and Valverde M (2006) Governmentality. Annual Review of Law and Social Science 2: 83-104.

Ruddock P (2007) Law as a preventative weapon against terrorism. In Lynch A, Macdonald E and Williams G (eds) Law and Liberty in the War on Terror. Sydney: The Federation Press: 380.

Steiker C (1998) Forward: The limits of the preventive state. Journal Of Criminal Law and Criminology 88(3): 771-808.

Stern J and Wiener JB (2006) Precaution against terrorism. Journal of Risk Research 9(4): 393447.

Sunstein C (2005) Laws of Fear: Beyond the Precautionary Principle. Cambridge: Cambridge University Press.

Tulich T (2012) A view inside the preventive state: Reflections on a decade of anti-terror law. Griffith Law Review 21(1) (forthcoming).

Valverde M (2011) Questions of security: A framework for research. Theoretical Criminology 15: 3-22.

Walker C (2011) Terrorism and the Law. Oxford: Oxford University Press. 
Williams G (2011) A decade of Australian anti-terror laws. Melbourne University Law Review 35(3): 1136-1176.

Zedner L (2007a) Pre-crime and post-criminology? Theoretical Criminology 11(2): 261-281.

Zedner L (2007b) Preventative justice or pre-punishment? The case of control orders. Current Legal Problems 60: 174-203.

Zedner L (2007c) Seeking security by eroding rights: The side-stepping of due process. In Goold B J and Lazarus L (eds) Security and Human Rights. Oxford: Hart Publishing: 257-275.

Zedner L (2008) Fixing the future? The pre-emptive turn in criminal justice. In McSherry B, Norrie A and Bronitt S (eds) Regulating Deviance: The Redirection of Criminalisation and the Futures of Criminal Law. Oxford: Hart Publishing: 35-58.

Zedner L (2009) Security. Abingdon: Routledge.

\section{Bills and legislation}

Crimes (Serious Sex Offenders) Act 2006 (NSW)

Criminal Code Act 1995 (Cth)

Security Legislation Amendment (Terrorism) Bill 2002 [No. 2] (Cth)

\section{Cases}

Chu Kheng Lim v Minister for Immigration, Local Government \& Ethnic Affairs (1992) 176 CLR 1 Lodhi $v$ R [2006] NSWCCA 121

$R v$ Lodhi [2006] NSWSC 691

Thomas v Mowbray [2007] 233 CLR 307

Veen $v$ The Queen (No 2) (1988) 164 CLR 465 